\title{
Histopathological Profile of Ovarian Tumours: A Two Year Retrospective Study
}

\author{
Dr. BVVD. Kiranmayi ${ }^{1}{ }^{2}$ Dr. Ch. Kishore Kumar, Dr. R. Vijaya Bhaskar ${ }^{3}$ \\ ${ }^{1}$ Associate Professor, Department of Pathology, Rangaraya Medical College, Kakinada, Andhra Pradesh, India \\ ${ }^{2}$ Assistant Professor, Department of Pathology, Rangaraya Medical College, Kakinada, Andhra Pradesh, India \\ ${ }^{3}$ Professor and Head, Department of Pathology, Rangaraya Medical College, Kakinada, Andhra Pradesh, India
}

\begin{abstract}
Introduction: Ovary is the commonest site of neoplastic and non-neoplastic lesions, can present in childhood to post menopausal age group. Materials and Methods: This is a retrospective study of 78 cases over a period of two years. Results: The total number of ovarian lesions studied during the study period were 78 cases, among them 74 cases (94.87\%) were neoplastic and 4 cases (5.12\%) were non-neoplastic. The non-neoplastic cases seen were endometriosis cysts and salpingo-oophoritis. Among the 74 neoplastic lesions 65 cases $(87.83 \%)$ were benign and 9 cases were $(12.15 \%)$ were malignant. In benign lesion most commonly seen are mucinous cystadenomas accounting for 32 cases (43.24\%) followed by serous cystadenomas accounting for 15 cases (20.27\%). In malignant cases mucinous cystadenocarcinomas are the most common followed by serous cystadenocarcinomas and metastasis. Conclusion: The majority of ovarian lesions received for evaluation were benign and unilateral and suggests need for further effort to early diagnosis and management.
\end{abstract}

Keywords: Ovary, Non-neoplastic, Neoplastic, Benign, Malignant

\section{Introduction}

Ovarian neoplastic and non-neoplastic lesions possess great challenge to gynaecological oncologist. All the ovarian lesions presents as pelvic mass and non-neoplasticlesions often confused with neoplastic lesions. Therefore proper recognition and classification is needed to allow appropriate therapy [1].

Ovarian Cancer is the seventh leading cause of cancer death among women worldwide [2,3].Ovarian tumours are often difficult to detect until they are advanced in stage or size, as symptoms are vague and insidious.

Incidence of invasive epithelial ovarian cancer peaks at 5060 years of age. In post-menopausal women about $30 \%$ of ovarian neoplasms are malignant, whereas in the premenopausal patients only about $7 \%$ of ovarian epithelial tumours are frankly malignant [4].

\section{Materials and Methods}

A retrospective study of total 78 cases of non-neoplastic and neoplastic lesions of ovary was conducted in the department of pathology, Rangaraya Medical College, Kakinada over a period of two years from Oct 2015 to Oct 2017. In our study all ovarian specimens obtained from hysterectomyspecimens with unilateral or bilateral adnexae, oophorectomy and / or cystectomy specimens received in the department. The specimens were analysed macroscopically for various parameters like external surface and cut sections with contents of cyst. The tissues were processed by routine paraffin techniques and sections stained with Haematoxylin and Eosin, examined microscopically and classified according to WHO classification.

\section{Results}

In our study a total of 78 cases were studied of which 73 (93.58\%) cases were unilateral and $5(6.41 \%)$ cases were bilateral. Patients in the age group 21-50 years showed majority of cases.

Table 1: Age wise distribution of patients with ovarian lesions

\begin{tabular}{|c|c|c|}
\hline Age & No. of Patients & Percentage \\
\hline$<20$ & - & - \\
\hline $21-30$ & 26 & $33.33 \%$ \\
\hline $31-40$ & 14 & 17.94 \\
\hline $41-50$ & 20 & $25.64 \%$ \\
\hline $51-60$ & 12 & $15.38 \%$ \\
\hline$>60$ & 6 & $7.69 \%$ \\
\hline
\end{tabular}

The lesions were classified as non-neoplastic lesions and neoplastic lesions, the neoplastic lesions as benign and malignant lesions. The non-neoplastic lesions constituted 4 cases $(5.12 \%)$ and the neoplastic lesions constituted 74 cases (94.87\%).

Table 2: Distribution of various neoplastic \& non-neoplastic lesions

\begin{tabular}{|c|c|c|}
\hline Age & Non-Neoplastic & Neoplastic \\
\hline$<20$ & - & - \\
\hline $21-30$ & 2 & 24 \\
\hline $31-40$ & 0 & 14 \\
\hline $41-50$ & 2 & 18 \\
\hline $51-60$ & 0 & 12 \\
\hline$>60$ & 0 & 6 \\
\hline Total & $\mathbf{4}$ & $\mathbf{7 4}$ \\
\hline
\end{tabular}

In our study among the 74 neoplastic lesions most common ones are surface epithelial tumours constituting 54 cases (72.97\%), germ cell tumours constituted 8 cases $(10.81 \%)$, sex-cord stromal tumours are 10 cases $(13.51 \%)$ and metastasis constituted of 2 cases $(2.7 \%)$.

\section{Volume 6 Issue 12, December 2017}

\section{www.ijsr.net}




\section{International Journal of Science and Research (IJSR) \\ ISSN (Online): 2319-7064}

Index Copernicus Value (2016): 79.57 | Impact Factor (2015): 6.391

Table 3: Distribution of various types of ovarian tumours

\begin{tabular}{|c|c|c|}
\hline Type of ovarian tumour & Frequency & Percentage \\
\hline Surface epithelial tumours & 54 & $72.97 \%$ \\
\hline Germcell tumours & 8 & $10.81 \%$ \\
\hline Sex-cord stromal tumours & 10 & $13.51 \%$ \\
\hline Metastasis & 2 & $2.7 \%$ \\
\hline Total & $\mathbf{7 4}$ & \\
\hline
\end{tabular}

In our study out of 54 cases of surface epithelial tumours the common tumours are mucinous tumours constituting 36 cases $(48.64 \%)$ followed by serous tumours constituting 18 cases $(24.32 \%)$.

Table 4: Frequency distribution of ovarian tumours

\begin{tabular}{|c|c|c|c|c|}
\hline $\begin{array}{c}\text { Types of } \\
\text { ovarian } \\
\text { tumour }\end{array}$ & \multicolumn{2}{|c|}{ Type of lesion } & $\begin{array}{c}\text { Total no. } \\
\text { of cases }\end{array}$ & Percentage \\
\hline \multirow{2}{*}{$\begin{array}{c}\text { Surface } \\
\text { epithelial } \\
\text { tumors }\end{array}$} & Benign & Serous tumors & 15 & $20.27 \%$ \\
\cline { 2 - 5 } & Mulignant & Serous tumors & 32 & $43.24 \%$ \\
\cline { 2 - 5 } & Mucinous tumors & 4 & $5.05 \%$ \\
\hline $\begin{array}{c}\text { Germ Cell } \\
\text { Tumours }\end{array}$ & Teratoma & 8 & $10.81 \%$ \\
\hline $\begin{array}{c}\text { Sex-Cord } \\
\text { Stromal } \\
\text { Tumours }\end{array}$ & Fibroma & 10 & $13.51 \%$ \\
\hline Metastasis & \multicolumn{2}{|c|}{} & 2 & $2.7 \%$ \\
\hline
\end{tabular}

\section{Discussion}

Ovarian cancer is the second leading cause of mortality among all gynaecological cancers [5]. Given the location of these paired organs and the mildness of symptoms associated with lesions arising in them, these lesions usually attain a very large size before they are detected and removed. Neoplastic disorders can arise from mullerian epithelium, germ cells are sex-cord stromal cells [6]. In our study 78 cases of non-neoplastic and neoplastic lesions were evaluated to study incidence, histogenesis and pathological features.

In our study $93.58 \%$ cases were unilateral and $6.41 \%$ were bilateral. These results were similar to the results obtained by Prabhakar et al [7], Couto et al [8] and Thakkar et al [9]. In our study the majority of patients were in the age group 21-40 years followed by the age group 41-60 years which is in concordance with the studies by Ramachandran et al [10] and Pilli et al [11]. In our study the non-neoplastic lesions were 4 cases $(5.12 \%)$ and neoplastic lesions were 74 cases $(94.87 \%)$. The percentage of non-neoplastic lesions were low when compared with studies done by Zaman et al [12] and Gurung et al [13].

In our study benign neoplastic lesions constituted 65 cases $(87.83 \%)$ and malignant lesions constituting 9 cases $(12.15 \%)$ which is showing concordance with Thakkar et al [9]. Histologically in our study surface epithelial tumours $(72.97 \%)$ were the most common category followed by sexcord stromal tumours $(13.51 \%)$ corresponding to the findings of Gupta et al [14]. In our study among benign surface epithelial tumours mucinous cystadenomas were the most common. Here we differ from the findings of Shah et al [15]. We encountered only 9 cases of malignant lesions in our study. They occured at different decades of life and showed no age predilection. We have not been able to elicit any reason for the low incidence of malignant neoplasms in our study.

\section{Conclusion}

Benign ovarian tumours were more common than malignant lesions in all age groups. Among all the tumours the surface epithelial lesions were most common lesions and the majority of lesions were of benign nature. Vague, insidious onset, dull pain in abdomen was the most common clinical presentation. So awareness among public and doctors, educating people, passive surveillance and community screening facility will be helpful in early detection of the ovarian lesions and tumours.

\section{Figures}

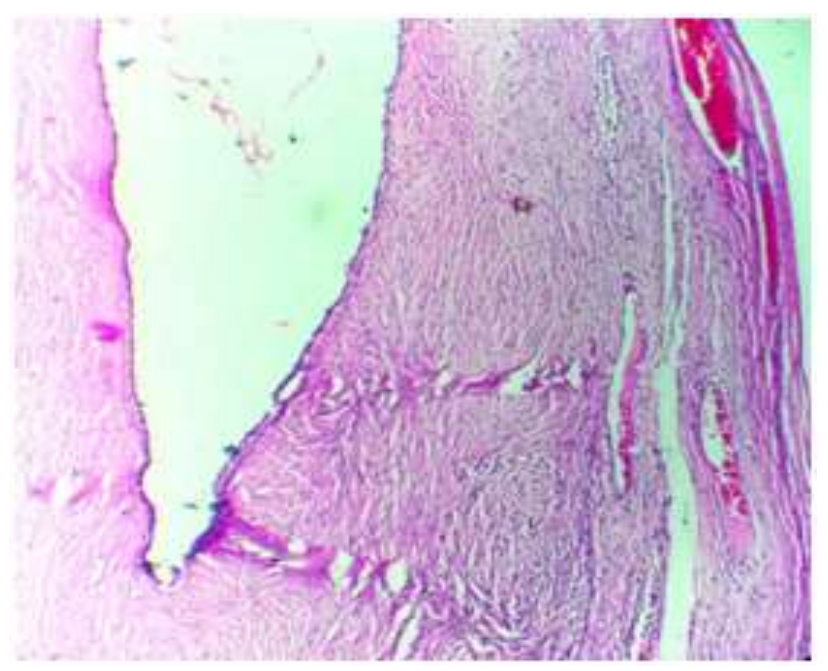

Figure 1: Serous cystadenoma

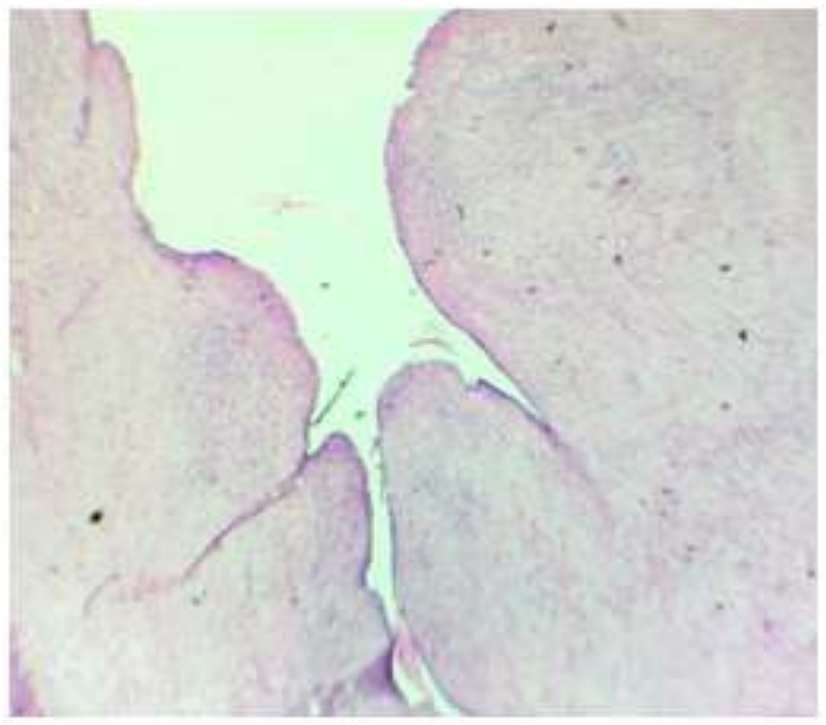

Figure 2: Serous cystadenofibroma

\section{Volume 6 Issue 12, December 2017}




\section{International Journal of Science and Research (IJSR) \\ ISSN (Online): 2319-7064 \\ Index Copernicus Value (2016): 79.57 | Impact Factor (2015): 6.391}

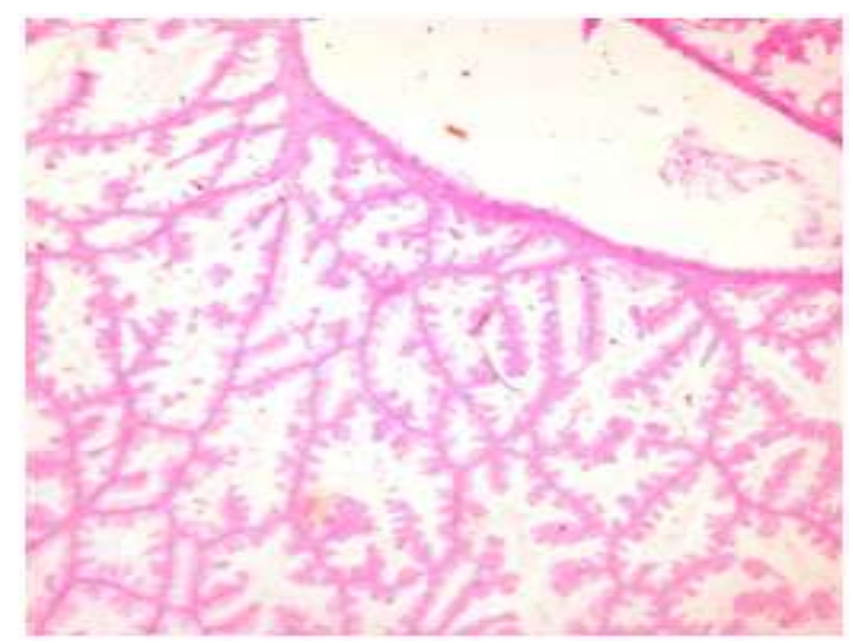

Figure 3: Mucinous cystadenoma

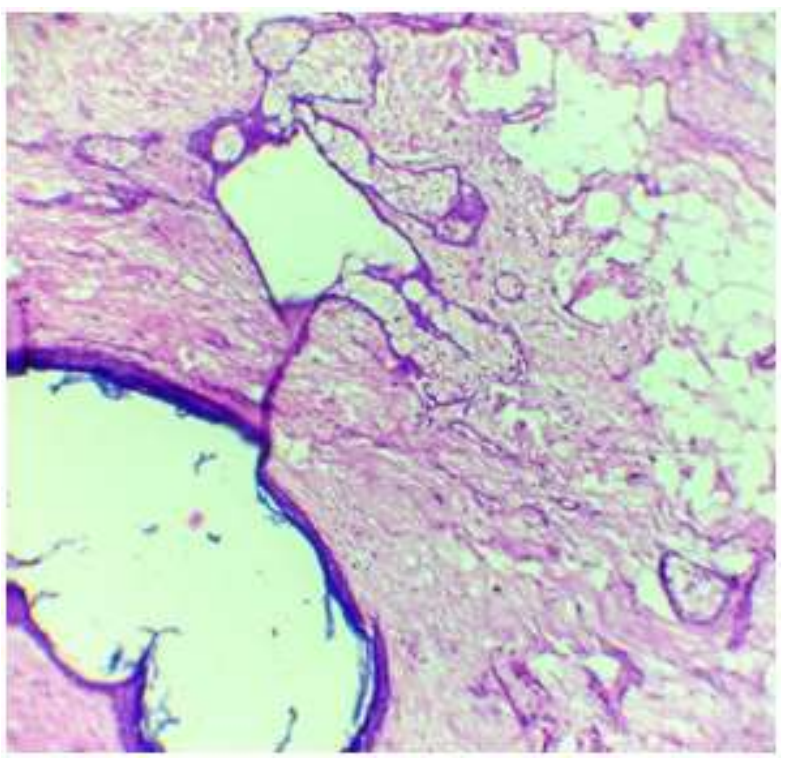

Figure 4: Teratoma

idemol. 2004; 159(4):319-35.

Available from: https://doi. org/10.1093/aje/kwh046

[6] Modi D, Rathod GB, Delwadia KN, Goswami HM Histopathological pattern of neoplastic ovarian lesions. IAIM. 2016;3(1):51-7.

[7] Prabhakar BR, Kalyani M. Ovarian tumors -prevalence in Punjab. Indian J Pathol Mirobiol. 1989;32(4):276-81.

[8] Couto F, Nadkarni NS, Rebello MJ. Ovarian tumors in Goa. A clinicopathological study. J Obstet Gynecol of India. 1993;43(3):408-12.

[9] Thakkar NN, Shah SN. Histopathological study of ovarian lesions. Int J Sci Research 2015; 4(10):1745-9.

[10] Ramachandran G, Harilal KR, Chinnamma K, Thangavelu H. Ovarian neoplasms -A study of 903 cases. J Obstet Gynecol India. 1972;22:309 -15.

[11] Pilli GS, Sunitha KP, Dhaded AV, Yenni VV. Ovarian tumors - a study of 282 cases. J Indian Med Associ. 2002;100(7):420-4.

[12]Zaman S, Majid S, Hussain M, Chugtai O, Mahboob J, Chugtai S. A retrospective study of Ovarian tumors and tumor - like lesions. J Ayub Med Coll Abbottabad. 2010;22(1):104-8.

[13] Gurung $\mathrm{P}$, Hirachand S, Pradhanang S. Histopathological study of ovarian cystic lesions. J Inst Med. 2013;35(3):44-7.

[14] Gupta N, Bisht D, Agarwal AK, Sharma VK. Retrospective and prospective study of ovarian tumours and tumour-like lesions.Indian J Pathol Microbiol 2007;50:525-7.

[15] Shah S, Hishikar VA. Incidence and management of ovarian tumours. Bombay Hospital J 2008; 50:30-3.

\section{References}

[1] Srikanth S, Anandam G. Bilateral dermoid cyst of ovary. Med J DY Patil Univ. 2014; 7:4923. Available from: https:// doi.org/10.4103/0975-2870.135281

[2] Basu P, De P, Mandal S, Ray K, Biswas J. Study of 'patterns of care' of ovarian cancer patients in a specialized cancer institute in Kolkatta, eastern India. Indian J Cancer. 2009; 46(1):28-33. PMid:19282563. Available from: https://doi. org/10.4103/0019509X.48592

[3] Mondal SK, Banyopadhyay R, Nag DR, Roychowdhury S, Mondal PK, Sinha SK. Histologic pattern, bilaterality and clinical evaluation of 957 ovarian neoplasms: A 10year study in a tertiary hospital of eastern India. J Can Res Ther. 2011; 7:433-7. PMid:22269405Available from: https://doi. org/10.4103/0973-1482.92011

[4] Berek JS, Natarajan S. Ovarian and fallopian tube cancer. In: Berek JS, editor. Berek and Novak's Gynecology. 14th ed. New Delhi: Wolters Kluwer Health (India) private Limited; 2007. p. 1457-47

[5] Modugno F. Ovarian cancer and polymorphisms in the androgen and progesterone receptor genes. Am J Ep-

Volume 6 Issue 12, December 2017

\author{
www.ijsr.net
}

Licensed Under Creative Commons Attribution CC BY 